\title{
MATHEMATICAL MODEL OF METHANE REPLACEMENT PROCESS IN GAS HYDRATE WITH CARBON DIOXIDE IN A POROUS LAYER
}

\author{
M.K. Khasanov, M.V. Stolpovsky, S.R. Kildibaeva
}

Sterlitamak Branch of the Bashkir State University, Sterlitamak, Russian Federation

E-mail: hasanovmk@mail.ru, s_maxim.pmm@mail.ru, freya.13@mail.ru

\begin{abstract}
In this article we construct a mathematical model and examine the characteristics of the injection of carbon dioxide into the natural layer, rich of the methane and its hydrate in its initial state. We consider the case in which due to the injection of carbon dioxide in the layer two areas are formed: in the first (proximal) region the pores of the layer are saturated with carbon dioxide and its hydrate but in the second (distant) region the pores of the layer are saturated with methane and its hydrate. In the numerical experiments it was established when the pressure increasing on the right border of the layer and decreasing the permeability of the layer or of the pressure of the of carbon dioxide injected, the temperature of the layer can rise at the front of the replacement above the equilibrium temperature of gas hydrate decomposition of methane that corresponds to the appearance of the dissociation border of gas hydrate to methane and water.
\end{abstract}

Keywords: gas hydrate; porous layer; methane; carbon dioxide; replacement.

\section{Introduction}

The gas hydrates due to their possible use as energy resources and wide dissemination attract attention of oil companies and scientists. The first mention of the extraction of gas hydrate refers to the beginning of 70 of the 20th century in the Messoyakh field. In the early 21st century the works on the extraction of gas hydrate were carried out in the areas permafrost in Canada. Modern methods of extraction of the hydrate are based on the injection of warm water and lower pressure but both methods are energy-intensive and are accompanied by the release of by-products (water and sand) [1]. Experts have estimated that about $99 \%$ of hydrate deposits are located on the bottom of the world's ocean [2]. Hydrate extraction from these deposits is hazardous due to the allocation of large amounts of water and the destruction of the bottom. To avoid breaking strength of rocks a method was proposed for replacement of methane gas hydrate with carbon dioxide $[3,4]$. In this case, water is not allocated, since methane hydrate is replaced by the hydrate of carbon dioxide. The first experiments on the replacement of methane hydrate with carbon dioxide were carried out in 2011 on the North Slope of Alaska [5]. To date a series of laboratory experiments was conducted which have studied the kinetics of hydrate formation, dependence of the hydrate formation on the permeability, mineralization of water and method of injection of carbon dioxide.

Mathematical models of injection of carbon dioxide into the layer containing methane and its hydrate are presented in the works $[6,7]$. However, the solution of the problem in these studies is constructed in self-similar approximation for semi-infinite layer. In the present work, in contrast to $[6,7]$ the finite length of the layer is considered and the effect of pressure on the outside border to the peculiarities of the replacement process are investigated. 


\section{Problem Statement}

Let's consider a porous layer that is filled with methane and methane hydrate with the saturation $\nu$ in the initial moment of time. The upper and the bottom of the layer are impermeable, the pressure $p_{0}$ and the temperature $T_{0}$ of the layer correspond to the conditions of stable existence of a mixture of methane and its hydrate:

$$
t=0, x>0: T=T_{0}, p=p_{0}, S_{h}=\nu .
$$

Carbon dioxide in the gaseous state starts to inject through the left border of the layer $(x=0)$. The pressure $p_{e}$ and temperature $T_{e}$ of carbon dioxide is kept constant and correspond to the existence conditions of heterogeneous mixture of carbon dioxide and its hydrate:

$$
t>0, x=0: T=T_{e}, p=p_{e} .
$$

Values of pressure and temperature on the phase diagram in the case of the description of the curve "gas-water-hydrate" are described by the equation [8]:

$$
p=p_{s 0} \exp \left(\frac{T-T_{0}}{T_{*}}\right)
$$

where $p_{s 0}$ is the equilibrium pressure corresponding to the temperature $T_{0}, T_{*}$ is an empirical parameter, that depends on the type of gas hydrate.

We consider the flow in porous layers as laminar, and the injection process is faster than the diffusion process. In addition, the viscosity of carbon dioxide is approximately one and a half times higher than the viscosity of methane. In this regard, we can neglect mixing of gases and consider a stable front displacement of methane with carbon dioxide. Due to these factors, we can assume that two regions are formed during the injection of carbon dioxide. The pores of the layer are saturated with carbon dioxide and its hydrate in the proximal range and the pores of the layer are saturated with methane and its hydrate in the distant range. With all the assumptions the replacement of methane by carbon dioxide in the gas hydrate occurs on the front movable surface completely, separating these two areas.

\section{Basic Equations}

With the above assumptions the system of equations describing the filtration and heat transfer process within a porous medium and including the laws of conservation of mass and energy, Darcy's law and state equation in the rectilinear-parallel case has the form [9-12]:

$$
\left\{\begin{array}{l}
\frac{\partial}{\partial t}\left(\rho_{i} \phi S_{i}\right)+\frac{\partial}{\partial x}\left(\rho_{i} \phi S_{i} v_{i}\right)=0, \\
\frac{\partial}{\partial t}(\rho C T)+\rho_{i} c_{i} \phi S_{i} v_{i} \frac{\partial T}{\partial x}=\frac{\partial}{\partial x}\left(\lambda \frac{\partial T}{\partial x}\right), \\
\phi S_{i} v_{i}=-\frac{k_{i}}{\mu_{i}} \frac{\partial p}{\partial x}, \\
\rho_{i}=p / R_{g i} T .
\end{array}\right.
$$

Here and further the subscripts $i=c, m$ correspond to the parameters of carbon dioxide and methane: $p$ is pressure; $T$ is temperature; $\phi$ is porosity; $\rho_{i}$ is real density; $v_{i}$ is velocity, $k_{i}$ is permeability, $c_{i}$ is specific mass heat, $R_{g i}$ is gas constant, $\mu_{i}$ is dynamic viscosity of 
$i$-phase, $S_{i}$ is pore saturation of $i$-phase; $\lambda$ is the conductivity factor of the system, $\rho C$ is specific volume heat. We use the formula of Kozeny to describe the dependence of the phase permeability factor $k_{i}$ for $i$-gas phase on $S_{i}$ gas saturation and $k_{0}$ absolute permeability:

$$
k_{i}=k_{0} S_{i}^{3},(i=c, m) .
$$

Subject to replacement, the conditions of mass balance of carbon dioxide and methane at the border between the regions will take the form of:

$$
\left\{\begin{array}{l}
\phi S_{c} \rho_{c}\left(v_{c}-\dot{x}_{(n)}\right)=\phi S_{h c} \rho_{h c} G_{c} \dot{x}_{(n)}, \\
\phi S_{m} \rho_{m}\left(v_{m}-\dot{x}_{(n)}\right)=\phi S_{h m} \rho_{h m} G_{m} \dot{x}_{(n)},
\end{array}\right.
$$

where $\rho_{h i}$ is hydrate density and $S_{h i}$ is hydrate saturation of $i$-phase, $\dot{x}_{(n)}$ is border velocity of the phase transitions, $G_{c}$ и $G_{m}$ are the relative mass concentration of carbon dioxide and methane in the gas hydrate. Here and further the lower subscript $n$ refers to the parameters at the border between regions.

The conditions of mass balance and heat at the border between regions with (4) and Darcy's law can be written in the following form:

$$
\begin{gathered}
-\frac{k_{c}}{\mu_{c}} \frac{\partial p_{(1)}}{\partial x}=\phi\left(\frac{\rho_{h c}}{\rho_{c}} S_{h c} G_{c}+S_{c}\right) \dot{x}_{(n)}, \\
-\frac{k_{m}}{\mu_{m}} \frac{\partial p_{(2)}}{\partial x}=\phi\left(\frac{\rho_{h m}}{\rho_{m}} S_{h m} G_{m}+S_{m}\right) \dot{x}_{(n)}, \\
\left\{\begin{array}{l}
\phi S_{h c} \rho_{h c}\left(1-G_{c}\right) \dot{x}_{(n)}=\phi S_{h m} \rho_{h m}\left(1-G_{m}\right) \dot{x}_{(n)}, \\
\lambda \frac{\partial T_{(1)}}{\partial x}-\lambda \frac{\partial T_{(2)}}{\partial x}=\phi\left(S_{h c} \rho_{h c} L_{h c}-S_{h m} \rho_{h m} L_{h m}\right) \dot{x}_{(n)} .
\end{array}\right.
\end{gathered}
$$

Here $L_{h i}$ is heat formation of hydrate of $i$-phase $(i=c, m) ; \rho_{(j)}$ and $T_{(j)}$ is pressure and temperature in the $j$-region, lower subscripts $j=1,2$ are defined for the parameters of the 1-st and 2-nd regions.

The temperature and the pressure at the border between the regions should be continuous:

$$
p_{n(1)}=p_{n(2)}=p_{(n)}, T_{n(1)}=T_{n(2)}=T_{(n)} .
$$

The saturation of the layer by methane hydrate in the second region is presented as $S_{h m}=\nu$. So, the value of hydrate saturation in the first zone can be found from the third equation of the system (5), which is a condition for the mass balance of water bound in the hydrate:

$$
S_{h c}=\rho_{h m}\left(1-G_{m}\right) \nu / \rho_{h c}\left(1-G_{c}\right) .
$$

The problem in the question describing the changes in temperature $\Delta T=T_{e}-T_{0}$ are insignificant in the filtration region $\left(\Delta T \ll T_{0}\right)$. Therefore, the summand of the piezoconductivity equation, which is responsible for the temperature variability, is inessential. With this in mind, on the basis of system (2), the equations of piezoconductivity and thermal diffusivity can be written as:

$$
\frac{\partial p_{(j)}^{2}}{\partial t}=\chi_{(j)}^{(p)} \frac{\partial}{\partial x}\left(\frac{\partial p_{(j)}^{2}}{\partial x}\right), \quad(j=1,2),
$$




$$
\frac{\partial T_{(j)}}{\partial t}=\chi^{(T)} \frac{\partial}{\partial x}\left(\frac{\partial T_{(j)}}{\partial x}\right)+\chi^{(T)} \operatorname{Pe}_{(j)} \frac{\partial p_{(j)}^{2}}{\partial x} \frac{\partial T_{(j)}}{\partial x}, \quad(j=1,2),
$$

where $\chi_{(1)}^{(p)}=\frac{k_{c} p_{(1)}}{\mu_{c} \phi\left(1-S_{h c}\right)}, \chi_{(2)}^{(p)}=\frac{k_{m} p_{(2)}}{\mu_{m} \phi(1-\nu)}, \mathrm{Pe}_{(1)}=\frac{\rho_{0 c} C_{c} k_{c}}{2 \lambda \mu_{c} p_{(1)}}, \mathrm{Pe}_{(2)}=\frac{\rho_{0 m} C_{m} k_{m}}{2 \lambda \mu_{m} p_{(2)}}, \chi^{(T)}=\frac{\lambda}{\rho C}$.

\section{The Results of the Calculations}

The solution of the problem (8), (9) with conditions (5) - (7) at the border of the phase transition was carried out by the method of catching the front into the node of the spatial mesh with a step $h=L / n$, where $n$ is the number of breaking points [13]. It was believed that the unknown time step $\tau$, which is in the course of solving the problem, the phase transition front moves through a coordinate grid for the value $h$. The equation system in the partial derivatives (5) - (9) was given in the implicit finite-difference form. At each time step, making precise the distributions of pressure and temperature as well as time step were carried out by the method of iterations to the given accuracy. So, if at some time step, pressure and temperature distributions are known their precise is as follows. The pressure distribution in the first region (saturated with carbon dioxide) is determined from the piezoconductivity equation (8) with border conditions $\left(x=0, p=p_{e}\right)$ and (5), and due to the pressure value already found at the border and the condition $\left(x=L, p=p_{0}\right)$ the distribution of pressure in the second zone (saturated with methane) will be found too. The temperature distribution is found from the equation of thermal conductivity (9) subject to the conditions (7). The next approximation time step carries out according to the formula $\tau=\sqrt{\tau_{1} \cdot \tau_{2}}$, where the "intermediate" time steps are $\tau_{1}$ and $\tau_{2}$, which were determined from the conditions (6) and (7).

System parameters: $\phi=0,1, L=100 \mathrm{~m}, m=0,2, \quad \nu=0,4$, $p_{0}=3 \mathrm{MPa}, \quad p_{e}=3,3 \mathrm{MPa}, T_{0}=274 \mathrm{~K}, T_{e}=276 \mathrm{~K}, \quad G_{c}=0,28$, $G_{m}=0,13, \quad k_{0}=2 \cdot 10^{-15} \mathrm{~m}^{2}, \quad T_{*}=10 \mathrm{~K}, \quad p_{s 0}=2,87 \mathrm{MPa}, \lambda=2$ $\mathrm{W} /(\mathrm{m} \cdot \mathrm{K}), \quad \rho C=2,5 \cdot 10^{6} \mathrm{~W} /(\mathrm{m} \cdot \mathrm{K}), \rho_{h c}=1100 \mathrm{~kg} / \mathrm{m}^{3}, \quad \rho_{h m}=900 \mathrm{~kg} / \mathrm{m}^{3}$, $C_{c}=800 \mathrm{~J} /(\mathrm{kg} \cdot \mathrm{K}), C_{m}=1560 \mathrm{~J} /(\mathrm{kg} \cdot \mathrm{K}), R_{g c}=189 \mathrm{~J} /(\mathrm{kg} \cdot \mathrm{K}), R_{g m}=520 \mathrm{~J} /(\mathrm{kg} \cdot \mathrm{K})$, $L_{h m}=4,5 \cdot 10^{5} \mathrm{~J} / \mathrm{kg}, L_{h c}=4,1 \cdot 10^{5} \mathrm{~J} / \mathrm{kg}, \mu_{c}=1,4 \cdot 10^{-5} \mathrm{~Pa} \cdot \mathrm{c}, \mu_{m}=10^{-5} \mathrm{~Pa} \cdot \mathrm{c}$, $T_{c *}=7,6 \mathrm{~K}, T_{m *}=10 \mathrm{~K}, p_{s 0 c}=1,29 \mathrm{MPa}, p_{s 0 m}=2,87 \mathrm{MPa}$.

Fig. 1 shows the dependence of temperature and pressure on the coordinate at time $t=200$ days. According to Fig. 1 the layer temperature (continuous line) in the region saturated by gas hydrate of methane is below the equilibrium temperature of decomposition of gas hydrate of methane corresponding calculated pressure distribution (dashed line). Therefore, in this case, the solution with one border of phase transitions isn't contradictory.

Fig. 2 shows the temperature dependence at the front of the replacement (continuous line), the equilibrium temperature of decomposition of methane gas hydrate corresponding to the pressure at the border of the phase transition (dashed line) and the coordinates of the given border on the pressure of the injected gas $(a)$, pressure on the layer right border (b) as well as absolute permeability (c) at time $t=120$ days. According to Fig. 2, when the injection and permeability pressure decreasing and also the pressure increasing on the right border of the layer the temperature increasing is observed at the front of the replacement. This is because in this case the front replacement coordinate reduces and accordingly, the influence of the left hotter border $\left(T_{e}>T_{0}\right)$ increases for this front temperature. In this regard, at low values of injection pressure and permeability as well 

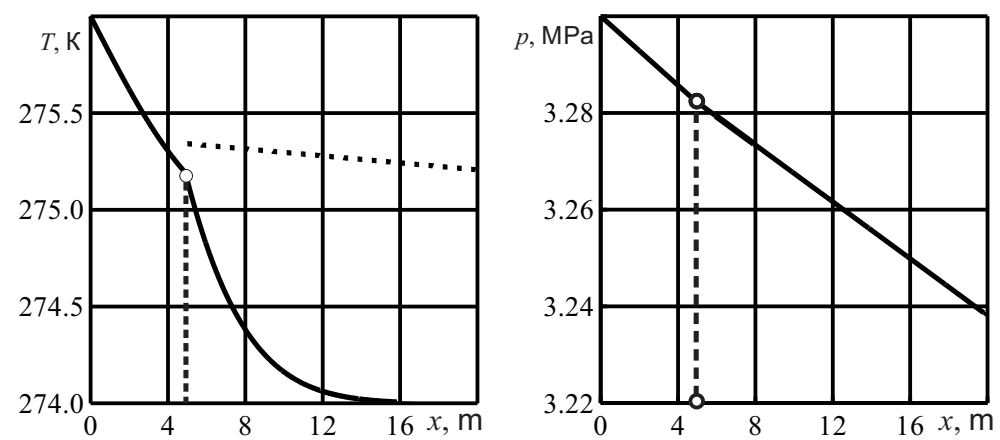

Fig. 1. Temperature and pressure distribution of the layer during the time $t=200$ days at $=3,3 \mathrm{MPa}$

as at the high pressure on the right border of the layer the temperature of the layer at the front of replacement rises above the equilibrium temperature of decomposition of methane gas hydrate that corresponds to the appearance of the intermediate region saturated with methane and water i.e. to the mode with the second border of phase transitions where the decomposition of the $\mathrm{CH}_{4}$ hydrate into methane and water takes place.
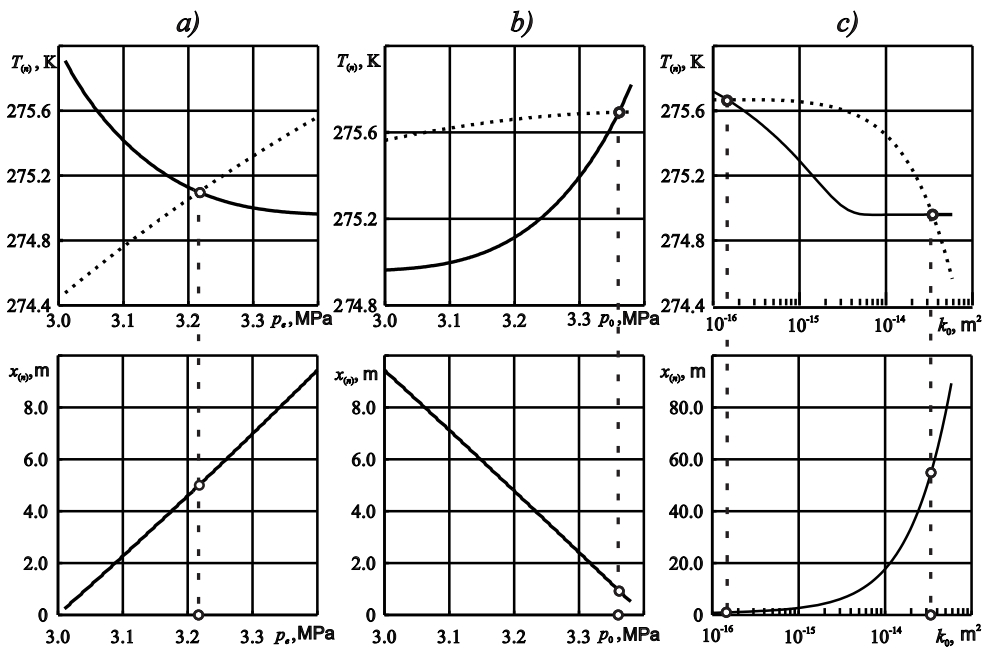

Fig. 2. Temperature dependence at the front of the substitution (continuous line), the equilibrium temperature of decomposition of gas hydrate of methane corresponding to the pressure at the border of the phase transition (dashed line) and the coordinates of the given border from the pressure of the injected gas $(a)$, pressure at the layer right border (b) as well as absolute permeability $(c)$ at time $t=120$ days

Acknowledgements. This work was financially supported by the grant of Russian Science Foundation (project № 17-79-20001).

\section{References}

1. Makogon Y.F., Omelchenko R.Y. [Messoyakha - Gas Hydrate Deposit, Role and Significance]. Geologiya i poleznyye iskopayemyye mirovogo okeana [Geology and Minerals of the World Ocean], 2012, no. 3, pp. 5-19. (in Russian) 
2. Herath D., Khan F. Probabilistic Estimation of Hydrate Formation. Journal of Petroleum Science and Engineering, 2015, vol. 135, pp. 32-38.

3. Nago A., Nieto A. Natural Gas Production from Methane Hydrate Deposits Using $\mathrm{CO}_{2}$ Clathrate Sequestration: State-of-Art Review and New Technical Approaches. Journal of Geological Research, 2011, p. 239397. Available at: http://www.hindawi.i.com/jornal/jgr/2011/239397. DOI: 10.1155/2011/239397.

4. Parshall J. Production Method for Methane Hydrate Sees Scientific Success. Journal of Petroleum Technology, 2012, vol. 64, no. 8, pp. 50-51.

5. Akserold S.M. [Development of Deposits of Methanehydrates Method of Substitution of Methane with Carbon Dioxide (Materials of Foreign Literature)]. Karotazhnik [Well Logger], 2014, no. 8 (242), pp. 70-102. (in Russian)

6. Khasanov M.K., Shagapov V.Sh. Methane Gas Hydrate Decomposition in a Porous Medium Upon Injection of a Warm Carbon Dioxide Gas. Journal of Engineering Physics and Thermophysics, 2016, vol. 89, no. 5, pp. 1123-1133.

7. Shagapov V.Sh., Khasanov M.K., Musakaev N.G., Ngoc Hai Duong. Theoretical Research of the Gas Hydrate Deposits Development Using the Injection of Carbon Dioxide. International Journal of Heat and Mass Transfer, 2017, vol. 107, pp. 347-357.

8. Byk S.Sh. Gazovyye gidraty [Gas Hydrates]. Moscow, Khimiya, 1980.

9. Tsypkin G.G. Formation of Carbon Dioxide Hydrate at the Injection of Carbon Dioxide into a Depleted Hydrocarbon Field. Fluid Dynamics, 2014, vol. 49, no. 6, pp. 789-795.

10. Khasanov M.K. Investigation of Regimes of Gas Hydrate Formation in a Porous Medium, Partially Saturated with Ice. Thermophysics and Aeromechanics, 2015, vol. 22, no. 2, pp. 255-265.

11. Khasanov M.K., Gimaltdinov I.K., Musakaev N.G. Features of the Decomposition of Gas Hydrates with the Formation of Ice in a Porous Medium. Journal of Engineering Physics and Thermophysics, 2015, vol. 88, no. 5, pp. 1052-1061.

12. Shagapov V.S., Khasanov M.K., Gimaltdinov I.K., Stolpovsky M.V. The Features of Gas Hydrate Dissociation in Porous Media at Warm Gas Injection. Thermophysics and Aeromechanics, 2013, vol. 20, no. 3, pp. 347-454. (in Russian)

13. Shagapov V.Sh, Khasanov M.K., Gimaltdinov I.K., Stolpovskii M.V. Numerical Modeling of Formation of a Gas Hydrate in a Finite-Length Porous Bed Purged by a Gas. Journal of Applied Mechanics and Technical Physics, 2011, vol. 52, no. 4, pp. 599-607. (in Russian)

Received October 9, 2017

УДК 519.6:532.546

DOI: $10.14529 / \mathrm{mmp} 170412$

\section{МАТЕМАТИЧЕСКАЯ МОДЕЛЬ ПРОЦЕССА ЗАМЕЩЕНИЯ МЕТАНА В ГАЗОГИДРАТЕ НА ДИОКСИД УГЛЕРОДА В ПОРИСТОМ ПЛАСТЕ}

\section{М.К. Хасанов, М.В. Столповский, С.Р. Килъдибаева}

Стерлитамакский филиал Башкирского государственного университета, г. Стерлитамак, Российская Федерация

В работе построена математическая модель и исследуются особенности инжекции диоксида углерода в природный пласт, насыщенный в исходном состоянии метаном и 
его гидратом. Рассматривается случай, при котором вследствие закачки диоксида углерода в пласте формируются две области: в первой (ближней) области поры пласта насыщены диоксидом углерода и его гидратом, а во второй (дальней) области поры пласта насыщены метаном и его гидратом. В ходе проведенного численного эксперимента было установлено, что при повышении давления на правой границе пласта, понижении проницаемости пласта или давления нагнетаемого диоксида углерода, температура пласта на фронте замещения может подниматься выше равновесной температуры разложения газогидрата метана, что соответствует возникновению границы диссоциации газогидрата на метан и воду.

Ключевые слова: газовый гидрат; пористый пласт; метан; диоксид углерода; замещение.

\section{Литература}

1. Макогон, Ю.Ф. Мессояха - газогидратная залежь, роль и значение / Ю.Ф. Макогон, Р.Ю. Омельченко // Геология и полезные ископаемые мирового океана. - 2012. - № 3. C. $5-19$.

2. Herath, D. Probabilistic Estimation of Hydrate Formation / D. Herath, F. Khan // Journal of Petroleum Science and Engineering. - 2015. - V. 135. - P. 32-38.

3. Nago, A. Natural Gas Production from Methane Hydrate Deposits Using $\mathrm{CO}_{2}$ Clathrate Sequestration: State-of-Art Review and New Technical Approaches / A. Nago, A. Nieto // Journal of Geological Research. - 2011. URL: http://www.hindawi.i.com/jornal/jgr/2011/239397 (дата обращения 09.05.2017)

4. Parshall, J. Production Method for Methane Hydrate Sees Scientific Success / J. Parshall // Journal of Petroleum Technology. - 2012. - V. 64, № 8. - P. 50-51.

5. Аксерольд, С.М. Разработка залежей метаногидратов методом замещения метана углекислым газом (по материалам зарубежной литературы) / С.М. Аксерольд // Каротажник. - 2014. - № 8 (242). - С. 70-102.

6. Хасанов, М.К. Разложение газогидрата метана в пористой среде при инжекции теплого углекислого газа / М.К. Хасанов, В.Ш. Шагапов // Инженерно-физический журнал. 2016. - № 5. - C. 1129-1140.

7. Shagapov, V.Sh. Theoretical Research of the Gas Hydrate Deposits Development Using the Injection of Carbon Dioxide / V.Sh. Shagapov, M.K. Khasanov, N.G. Musakaev, Ngoc Hai Duong // International Journal of Heat and Mass Transfer. - 2017. - V. 107. - P. 347-357.

8. Бык, С.Ш. Газовые гидраты / С.Ш. Бык, Ю.Ф. Макогон, В.И. Фомина - М.: Химия, 1980 .

9. Tsypkin, G.G. Formation of Carbon Dioxide Hydrate at the Injection of Carbon Dioxide into a Depleted Hydrocarbon Field / G.G. Tsypkin // Fluid Dynamics. - 2014. - V. 49, № 6. P. $789-795$.

10. Khasanov, M.K. Investigation of Regimes of Gas Hydrate Formation in a Porous Medium, Partially Saturated with Ice / M.K. Khasanov // Thermophysics and Aeromechanics. 2015. - V. 22, № 2. - P. 255-265.

11. Хасанов, M.K. Особенности разложения газогидратов с образованием льда в пористой среде / М.К. Хасанов, Н.Г. Мусакаев, И.К. Гималтдинов // Инженерно-физический журнал. - 2015. - Т. 88, № 5. - С. 1022-1031.

12. Шагапов, В.Ш. Особенности разложения газовых гидратов в пористых средах при нагнетании теплого газа / В.Ш. Шагапов, М.К. Хасанов, И.К. Гималтдинов, М.В. Столповский // Теплофизика и аэромеханика. - 2013. - Т. 20, № 3. - С. 347-454. 
13. Шагапов, В.Ш. Численное моделирование образования газогидрата в пористом пласте конечной протяженности при продувке его газом / В.Ш. Шагапов, M.K. Хасанов, И.К. Гималтдинов, М.В. Столповский // Прикладная механика и техническая физика.2011. - Т. 52, № 4. - C. 116-126.

Марат Камилович Хасанов, кандидат физико-математических наук, доцент, кафедра «Прикладная информатика и программирование», Стерлитамакский филиал Башкирского государственного университета (г. Стерлитамак, Российская Федерация), hasanovmk@mail.ru.

Максим Владимирович Столповский, кандидат физико-математических наук, научный сотрудник, Стерлитамакский филиал Башкирского государственного университета (г. Стерлитамак, Российская Федерация), s_maxim.pmm@mail.ru.

Светлана Рустамовна Кильдибаева, кандидат физико-математических наук, доцент, кафедра «Прикладная информатика и программирование», Стерлитамакский филиал Башкирского государственного университета (г. Стерлитамак, Российская Федерация), freya.13@mail.ru.

Исследование выполнено за счет гранта Российского научного фонда (проект №17-79-20001).

Поступила в редакиию 9 октября 2017 г. 